Available online on 15.02.2020 at http://jddtonline.info
Open Access to Pharmaceutical and Medical Research
unrestricted non-commercial use, provided the original work is properly cited

Open Access

Review Article

\title{
General Health Benefits of Pranayama W.S.R. to Effects on Respiratory System: An Ayurveda Review
}

\section{Yogeshwar Ashok Tikle}

M.D. (Swasthavrittha), Associate Professor, Jupiter Ayurved Medical, College, Nagpur, Maharashtra, India

\begin{abstract}
Pranayama is traditional techniques practicing from ancient time of Indian civilization; it establishes balances of body, mind and spiritual health. Pranayama used for various purposes such as; maintaining health status \& beauty, delaying age and as therapeutic measure against many pathological conditions. Pranayama involves three stages of respiratory practice; Puraka (inhalation), Kumbhaka (retention) and Rechaka (exhalation). These stages when practices with respiratory control then offer several health benefits. Pranayama improves circulatory process of body, boost respiratory system and helps in pathological conditions like; asthma and rhinitis. Present article summarizes role of Pranayama on respiratory system and related diseases.
\end{abstract}

Keywords: Pranayama, Respiratory System, Puraka, Kumbhaka and Rechaka.

Article Info: Received 21 Nov 2019; Review Completed 26 Jan 2020; Accepted 30 Jan 2020; Available online 15 Feb 2020

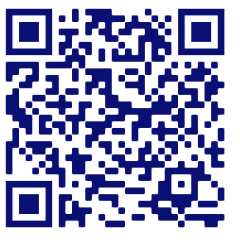

\section{Cite this article as:}

Tikle YA, General Health Benefits of Pranayama W.S.R. to Effects on Respiratory System: An Ayurveda Review, Journal of Drug Delivery and Therapeutics. 2020; 10(1-s):215-217 http://dx.doi.org/10.22270/jddt.v10i1-s.3898

\section{*Address for Correspondence:}

Maharashtra, India

\section{Introduction}

The word Pranayama can be elaborated as Prana (energy of life), Yama (control) and Ayama (extension) means control of "energy of life" or extension of Prana. Pranayama is a breathing practice that empowers lungs capacity and maintains rhythm of respiration. Pranayama helps to control inspiration and expiration. Pranayama can be considered as technique that control mind through the control of Vayu/air. Pranayama can be sub-divided into various types; Suryabhedana, Sheetalee, Ujjayee, Bhramaree, Bhastrikaa, Moorchaa, Sheetkaaree and Plaavinee 1-5.

The practice of Pranayama involves deep inspiration, holding of air followed by deep expiration and relaxation. Pranayama is science of breath that control energy of life, controls emotions and mind. Pranayama not only pacify biological energy but it also imparts spiritual energy and establishes harmony between body and nature.

Breathing forcefully and rapidly comes under Bhastrika Pranayama thus expands capacity of muscles and improves process of respiration; Figure 1 depicted major benefits of Pranayama on respiratory system

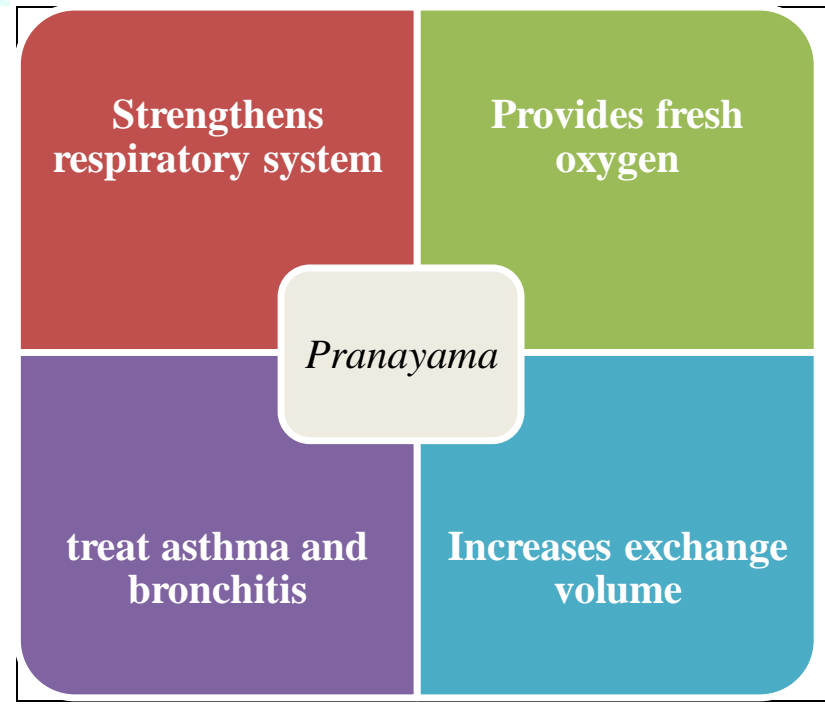

Figure 1: Major benefits of Pranayama on respiratory system 
Kapalabhati Pranayama can be considered as technique of skull shining breath, clear congestion and improve capacity of lungs. Suppress bloating and provide symptomatic relief in the condition of allergy and bronchitis.

Ujjayi Pranayama (victorious breath) expands lungs, improves focusing on breath, calm down mind and imparts good effects on respiratory system.

Sitali Pranayama means cooling exercise that imparts cooling effect on mind thus helps to regulate normal breathing and heart rate. The practice provides good health effects during summer and hot climatic conditions 3-8.

Pranayama involves four major stages as follows:

$\checkmark \quad$ Inhalation (Pooraka)

$\checkmark \quad$ Exhalation (Rechaka)

$\checkmark$ Retention of internal breathe (Antarkunbhaka)

$\checkmark \quad$ Retention of external breath (Bahir kumbhaka).

These techniques regulate flow of Prana in Nadis, provide flow of fresh air, stimulate functions of vital organs, maintain normal circulatory process and provide energy to perform various physiological activities.

\section{The general health benefits of Pranayama on Respiratory system:}

Pranayama control force of life that is Prana/Vayu/air therefore restores vital energy of body and mind. Pranayama provide calmness and relaxation, control intense emotional feelings and induces natural sleep and clear air pathways. Pranayama significantly helps in respiratory problems since it regulates breathing; detoxify body, improves respiration capacity; maintain rhythm of respiration and purifies air passages. Pranayama maintain harmony of sympathetic and parasympathetic system, causes bronchio-dilatation, reduces respiratory muscles tone and maintain supply of energy thus provide relief in problems related to respiratory system ${ }^{6-10}$.

* Pranayama optimizes uses of abdominal and diaphragmatic muscles to improve respiration.

* Strengthens respiratory system and facilitate extensions of muscle.

* Pranayama calm anxiety by controlling breath and heart rate.

* Pranayama provides fresh oxygenated blood to cell.

* Exhalation forces facilitate detoxification of organs.

* Pranayama helps to breath when person having breathing difficulties due to the lack of lung capacity/minor surgical intervention.

* Pranayama helps to treat respiratory problems like; asthma and bronchitis.

* Pranayama relaxes whole body thus imparts calming effect that regulates normal breathing and heart functioning.

* Pranayama increases exchange volume of lungs thus maintains inflow of fresh air and outflow of carbondioxide.

* Enhanced flow of air into lungs helps to improves overall pulmonary functions.
Pranayama mode of action towards the improvement of respiratory system:

Pranayama boosts elasticity and strength of collagen fibres thereby facilitates contraction and power of respiration.

Pranayama stimulates secretion of pulmonary surfactant which increases exchange volume of lungs.

Pranayama maintain level of prostaglandins which decreases bronchiolar smooth muscle tonicity leading to the enhanced flow of air into lungs.

It is stated that Pranayama stimulates stretch receptors which affects smooth muscles and improves lung capacities.

Pranayama relaxes skeletal muscles and thoracic cage, it also relaxes smooth muscles of bronchi thus boost pulmonary functions.

Extended expiratory period and voluntary breath holding period improves lungs capacity when these techniques of Pranayama performed regularly.

\section{Guidelines to perform Pranayama:}

Key features of Pranayama:

$>$ Inhalation, Retention \& Exhalation

$>$ Modulation in breathing speeds

$>$ Holding of breath

$>$ Shortening and elongation of breathing

As mentioned above one should maintain rhythm of inhalation, retention \& exhalation while performing Pranayama. The modulation of breathing is very important to maintain breath rate. Shortening, elongation and holding of breath depends upon regular practice which should be uniform throughout the period. The other major considerations related to Pranayama are as follows:

At initial stage it should be performed under guidance or after having proper training.

$>$ The nostrils should be dilated during inhaling and should be relax in normal position while exhaling.

$>$ Pranayama should be performed in morning time with empty stomach.

$>$ It should be performed at silent or peaceful place with focus attention.

$>$ Comfortable posture (Siddha yoni asana) is required for Pranayama since body should remain in relaxing condition.

> Spine, neck and head should remain in erect position.

$>$ One should use carpet/mat/cloth during practice to maximize energy conduction.

> Pranayama should be performed before meditation.

$>$ Never restrict breath.

\section{Precautions}

Pregnant women, diabetic patient, patient of high blood pressure and epileptic patient should take expert advice before performing Pranayama. Pranayama should not be performed during chronic illness. 


\section{Side effects}

Itching, tingling and modulation in body thermostat may occur at initial stage.

\section{Conclusion}

Pranayama strengthen respiratory muscles, enhance level of surfactant, stimulate stretch receptors, and relieve tension thus enhance lung volumes and capacities. It helps to cure obstructive respiratory diseases and bronchitis. Pranayama helps to maintain vital energy of body, maintain rhythms of body and detoxifies internal organs. Pranayama improves efficiency of respiratory system and control overall circulatory process of body.

\section{References}

1. Joshi LN, Joshi VD, Gokhale LV. Effect of short term Pranayama practice on breathing rate and ventilatory functions of lung. Indian J Physiol Pharmacol. 1992; 32:105-08.

2. Chanavirut R, Khaidjapho K, Jaree P, Pongnaratorn P. Yoga exercise increases chest wall expansion and lung volumes. Thai Journal of Physiological Sciences. 2006; 19(1):1-7.
3. Madan M, et al. Effect of yoga training on reaction time, respiratory endurance and muscle strength. Indian J Physiol Pharmacol. 1992; 36(4):229-33.

4. Shankarappa $V$, et al. The short term effect of pranayama on the lung parameters. Journal of Clinical and Diagnostic Research. 2012; 6(1):27-30.

5. Patil YR, Sawant RS. Study of effect of Bhastrika Pranayama on pulmonary function. International research journal of pharmacy. 2012; 3(3):204-207.

6. Yadav RK and Das S: Effect of Yogic practice on pulmonary functions in young females. Indian J PhysiolPharmacol. 2001; 4:493-6.

7. Rao MV. A Text Book of Swasthavritta.Reprint ed. Varanasi: Chaukhambha Orientalia; 2014: p.407.

8. Shankarappa V, Prashanth P, Annamalai N, Malhotra V. The short term effect of Pranayama on lung parameters. Jounal of clinical and diagnostic research. 2012; 6(1):27-30.

9. Makwana K, Khirwadkar N and Gupta H C. Effect of short term Yoga practice on the ventilatory function tests. Indian J Physiol Pharmacol.1988; 32(3):203-08.

10. Verma, S. and Gurvendra, A. A Study on the Effect of Collective Yogic Practices on Social Adjustment of Collage Students in Urban Area. International Journal of Science and Consciousness; 2016; 2(1):36-40. 